\title{
Is air-drying of plant-based food at low temperature really favorable? A meta-analytical approach to ascorbic acid, total phenolic and total flavonoid contents
}

\section{Libor Červenka, Zuzana Červenková \& Helena Velichová}

To cite this article: Libor Červenka, Zuzana Červenková \& Helena Velichová (2017): Is airdrying of plant-based food at low temperature really favorable? A meta-analytical approach to ascorbic acid, total phenolic and total flavonoid contents, Food Reviews International, DOI: 10.1080/87559129.2017.1307389

To link to this article: http://dx.doi.org/10.1080/87559129.2017.1307389

Accepted author version posted online: 16

Mar 2017.

Submit your article to this journal $\widetilde{T}$

View related articles $₫$

View Crossmark data $₫$ 


\section{Is air-drying of plant-based food at low temperature really}

\section{favorable? A meta-analytical approach to ascorbic acid, total phenolic and total flavonoid contents}

Running head: Meta-analysis of drying temperature

Libor Červenka ${ }^{a}$, Zuzana Červenková ${ }^{b}$, Helena Velichovác

${ }^{a}$ Department of Analytical Chemistry, Faculty of Chemical Technology, University of Pardubice, Pardubice, Czech Republic

${ }^{\mathrm{b}}$ Department of Clinical Subspecialities, Faculty of Health Studies, University of Pardubice, Pardubice, Czech Republic

${ }^{c}$ Department of Food Analysis and Chemistry, Faculty of Technology, Tomáš Bat’a University in Zlín, Zlín, Czech Republic

Address correspondence to Libor Červenka, Department of Analytical Chemistry, Faculty of Chemical Technology, University of Pardubice, Pardubice, 53210, Pardubice, Czech Republic.

E-mail: 1ibor.cervenka@upce.cz, tel.: +420 466037 718, fax:+420 466037068. 


\section{Abstract}

The aim of this work was to review the studies that evaluated the effect of drying temperature on the content of ascorbic acid (AA), total phenolic (TPC) and total flavonoid contents (TFC) in fruits and vegetables, and quantify whether drying at $40^{\circ} \mathrm{C}$ is more favorable than at higher temperatures. For the purpose of this study, AA, TPC and TFC values for $40^{\circ} \mathrm{C}$ were compared with those obtained at $50^{\circ} \mathrm{C}, 60^{\circ} \mathrm{C}$ and $70^{\circ} \mathrm{C}-80^{\circ} \mathrm{C}$. A meta-analysis was performed using the weighted response ratio calculated for each experiment. Despite the fact that other variables significantly influenced the nutrient content in individual experiments, the meta-analysis provided a general view on the effect of air-drying temperature on the quality of plant-based food products from outcomes of various studies.

Keywords: air drying; ascorbic acid; phenolics; flavonoids; temperature effect; response ratio;

\section{Introduction}

Drying (or dehydration) is a well known method for the preservation and increase of shelf life of fresh fruits, vegetables and other edible plant-based material. Various technologies of drying have been developed in order to minimize the losses of vitamins and other biologically active compounds. The combination of microwave, vacuum, infrared or freeze drying can reduce nutrient losses and improve the nutritional quality of dried fruits and vegetables.(1-3) However, these techniques are usually applied in industry and cannot be used as home-drying methods due to the technological barriers. For domestic purposes, drying with circulated hot air using kitchen oven or food dehydrator still prevails. This technique is increasingly utilized for the preparation of vegetarian or vegan foods, particularly for those who follow raw food diet. According to the 
popular book for raw food adherents (4), dehydration at temperatures not exceeding $46^{\circ} \mathrm{C}$ is allowed to preserve nutrients and enzymes in such prepared meal. This claim was supported by Sablani (3), who evaluated 28 studies regarding hot-air drying and concluded that the low drying temperatures favor nutrient retention in dried fruits and vegetables. Ascorbic acid (AA) degradation and retention in 60 fruit and vegetable species during various drying treatments were assessed by Santos and Silva (5). They indentified that temperature and time with combination of oxygen and area of surface exposed to the drying conditions are the most important parameters affecting ascorbic acid degradation. On the other hand, Oliveira et al. (1) found in their review that the relation between drying temperature and vitamin $\mathrm{C}$ losses were not always consistent. It should be noted that conclusions were based on authors' experience and knowledge, and did not quantitatively summarize the effect of drying temperature by combining the results from different researches.

Since ascorbic acid, phenolic and flavonoid compounds are essential substances found in many fruits and vegetables, and have an important health-promoting effect, the majority of researchers study the effect of drying conditions on their contents. (6) Ascorbic acid content usually decreased with the increase of temperature (2); however, experiments using drying at low temperatures remained contradictory in their results. For example, the same ascorbic acid retention was found for strawberry samples dried at $40^{\circ} \mathrm{C}$ and $50^{\circ} \mathrm{C}(7)$ whereas higher content of ascorbic acid was determined in fruits dried at temperature $>50^{\circ} \mathrm{C}$ in comparison with that of $40^{\circ} \mathrm{C}$ using hot-air drying. $(8,9)$ The effect of drying temperature on the total phenolic content (TPC) was examined in various plant-based materials and was found to be inconsistent in results. While decrease in TPC with the increase in temperature from $40^{\circ} \mathrm{C}$ to $70^{\circ} \mathrm{C}$ was published for cocoa bean (10), sweet corn (11), tomatoes (12), carrots (13), gac fruit (14), leaves of Stevia 
rebaudiana (15) or jaboticaba fruit (16), the increase in TPC with the increase of drying temperature was observed for apple (17), ginger rizome (18), cucumber (19) or quinoa seed (20). Total flavonoids content (TFC) also showed both decrease $(11,15,21,22)$ and increase trends (24-26) with the increase in temperature in the range from $40^{\circ} \mathrm{C}$ to $70^{\circ} \mathrm{C}$.

In this paper, a systematic review and statistical analysis of the effect of various drying temperatures on the content of ascorbic acid, total phenolics and flavonoids in edible plant-based material using meta-analysis are presented. Meta-analysis is a statistical method that summarizes the results of independent experiments and was primarily designed for medical, psychological and social sciences. (27) Combining the outcomes of various studies and calculating their effect sizes resulted in main conclusion whether the effect (treatment) is significant in comparison with the control. In a past decade, meta-analytical approach has been exploited for comparing the nutritional quality between conventional and organic dairy products (28) or meat (29) or measured the effect of technological processes on the content of vitamins (30), carotenoids (31), and pesticide residues (32) in foods. The method based on the response ratio $(R)$ was adopted from the study of Hedges et al. (33). The response ratio is the ratio of measured quantity in experimental and control groups; it measures the proportional changes resulted from an experimental treatment. This method was previously applied to the effects of various food processing techniques on pesticide residues (32) and pigment contents (31) in fruit and vegetables.

The aim of this work was to review the studies that have evaluated the effect of air drying of edible plant-based material in the temperature range from $40^{\circ} \mathrm{C}$ to $80^{\circ} \mathrm{C}$ on the content of ascorbic acid, total phenolics and flavonoids. An attempt to quantify the effect of drying at low temperature $\left(40^{\circ} \mathrm{C}\right)$ compared with products dried at higher temperatures has been made using 
meta-analysis.

\section{Methods}

\section{Literature search}

A literature search on effects of drying temperature on the ascorbic acid, total phenolic and flavonoid contents in fruits and vegetables was carried out on the Scopus and ISI Web of Knowledge databases in July 2016. The initial criteria for inclusion of a study in the metaanalysis were as follows; peer-reviewed journal written in English language, particular methods of drying (air-drying, oven-drying, conventional-drying), drying temperatures $\left(40^{\circ} \mathrm{C}\right.$ and then higher up to $80^{\circ} \mathrm{C}$ ) and the content expressed in dry weight (dw). Total phenolic and flavonoid contents should be expressed as gallic acid and catechin equivalents, respectively. The samples used for the meta-analysis have to be dried without any pre-drying treatment. The following combinations of keywords were used; "drying or dried", "fruit or vegetable", "ascorbic acid", "phenolic", "polyphenolic", "flavonoid", "antioxidant", "temperature effect". Title, authors and abstract were collected from both databases, combined and duplicates were removed. Then titles and abstracts were individually evaluated by each author in order to find relevant articles meeting the initial criteria. Downloading the full articles followed. If not available online, corresponding author was kindly requested for sending reprint. Reference sections of the retrieved articles were checked for additional studies.

\section{Data collection}

Only data from the studies with at least two samples and available standard deviation (SD) were used in meta-analysis. Results reported in tables were used directly; those in graphical form were treated as follows: first, corresponding author was kindly asked for numerical data and second, the figure was enlarged, printed and measured using a ruler as was previously described. (29) 
When concentration of target compounds was presented as a time-dependent relationship (i.e., kinetic data only in graphs), the numerical values with standard deviations were retrieved for the same time of drying. The concentrations of ascorbic acid, total phenolic and flavonoids contents in plant-based products were divided into the groups where those obtained at $40^{\circ} \mathrm{C}$ were used as a control. As treatment groups, data retrieved from drying experiments at $50^{\circ} \mathrm{C}, 60^{\circ} \mathrm{C}$ and $70^{\circ} \mathrm{C}-$ $80^{\circ} \mathrm{C}$ were used and abbreviated as LTD (low temperature difference), HTD (high temperature difference) and VHTD (very high temperature difference), respectively. All the concentrations of $\mathrm{AA}, \mathrm{TPC}$ and TFC were expressed in $\mathrm{mg}$ per $100 \mathrm{~g}$ of $\mathrm{dw}$.

\section{Meta-analysis calculation}

Since response ratio can be biased when quantifying the outcome from studies with small sample size, a simple formula for checking the relevance of every study to be incorporated into the metaanalysis was applied using mean $(X)$, sample size $(n)$ and standard deviation (SD) (34):

$$
-\left(\frac{4^{\frac{3}{2}}}{1+4}\right) \geq 3
$$

If the Eq. (1) is true, then a study meets inclusion criterion for the calculation of response ratio. Meta-analysis of response ratio was applied as described by Hedges et al. (33). The log response ratio $(L)$ was calculated for every experiment using formula $L=\ln R$, where $R=X_{\mathrm{T}} / \mathrm{X}_{\mathrm{C}} X_{\mathrm{C}}$ is the concentration of AA, TPC or TFC after drying at $40^{\circ} \mathrm{C}$ and $X_{\mathrm{T}}$ is the concentration of the same after drying at $50^{\circ} \mathrm{C}, 60^{\circ} \mathrm{C}$ and $70^{\circ} \mathrm{C}-80^{\circ} \mathrm{C}$. The sampling variability $(V)$ was calculated using Eq. 2

$$
=\frac{\left(\mathrm{SD}_{\mathrm{T}}\right)^{2}}{\mathrm{n}\left(\mathrm{X}_{\mathrm{T}}\right)^{2}}+\frac{\left(\mathrm{SD}_{\mathrm{C}}\right)^{2}}{\mathrm{n}\left(\mathrm{X}_{\mathrm{C}}\right)^{2}}
$$

A random effect model of meta-analysis was applied and the between-experiment variance $\left(\sigma^{2}\right)$ was estimated from the $Q$-statistic (a homogeneity test) at the significance level $\mathrm{P}=0.05$ of the 
$\mathrm{X}^{2}$-distribution at $k-1$ degree of freedom, where $k$ is the number of experiments:

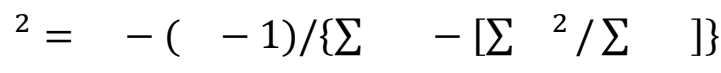

where

$$
=\sum \quad 2-\left(\sum \quad\right)^{2} / \Sigma
$$

and $\mathrm{W}_{\mathrm{i}}$ is the inverse value of sampling variability $\left(\mathrm{V}_{\mathrm{i}}\right)$. The weighted mean $\log$ response ratio $\left(L^{*}\right)$ was calculated as

$$
{ }^{*}=\sum^{*} / \sum^{*}
$$

where $W_{i}=1 /\left(V_{i}+\sigma^{2}\right)$

The standard error $(S E)$ of the weighted mean was calculated by

$$
\left({ }^{*}\right)=\left\{\left(1 / \Sigma^{*}\right)\left[1+4 \sum 1 / \mathrm{d}\left({ }^{*} /\right)^{2}\right]\left[{ }^{*}\left(\Sigma^{*}-{ }^{*}\right) /\left(\Sigma^{*}\right)^{2}\right]\right\}^{1 / 2}
$$

where $\mathrm{d} f=2 n-2$ (degrees of freedom including both samples dried at $40^{\circ} \mathrm{C}$ and higher temperature). The confidence interval for the average log response ratio was calculated as

$$
*^{*}-/ 2 \quad\left({ }^{*}\right) \leq<{ }^{*}+/ 2 \quad\left({ }^{*}\right)
$$

where $z_{\alpha / 2}$ is the $100(1-\alpha / 2) \%$ point of the standard normal distribution. The weighted mean response ratio $\left(R^{*}\right)$ was obtained by taking the antilogarithm. The $\mathrm{P}$ value reflecting the statistical significance of estimated $R^{*}$ was calculated from a confidence interval according to procedure described by Altman and Bland (35). If the upper and lower limits of a $95 \%$ confidence interval are $u$ and $l$ respectively, then standard error $S E_{p}$ was calculated using formula:

$$
=(-) /(2 \times 1.96)
$$


a $z$ statistic was estimated from response ratio $R^{*}$ using formula:

$$
=* /
$$

followed by the calculation of $P$ value using formula:

$$
=\left(-0.717 \times-0.416 \times{ }^{2}\right)
$$

\section{Results and discussion}

\section{Literature search and data collection}

In a summary, the databases search revealed 1140 articles from 1990 to 2016 for all the variables. After removing duplicates (495 articles), 94 articles were selected on the basis of information included in title and abstract. A detailed study of materials and methods section of each article was then performed to be sure that only conventional drying techniques at $40^{\circ} \mathrm{C}$, $50^{\circ} \mathrm{C}, 60^{\circ} \mathrm{C}$ and $70^{\circ} \mathrm{C}-80^{\circ} \mathrm{C}$ will be used for meta-analysis ( 3 articles were excluded). Based on the result section screening, 45 articles were removed due to the absence of sample size, standard deviation or inappropriate expression of results (\% of retention, wet basis, kinetic equations, composite design etc.). When means and standard deviations were estimated from graph using the ruler, the percentage error did not exceed $2.5 \%$ for mean and $5.0 \%$ for standard deviation. The data were also extracted from the graphs describing kinetics of degradation in three research articles, since authors presented their results with standard deviation. $(13,36,37)$ In that case, the data were estimated for a specific drying time. An average mean and pooled standard deviation were calculated for experiment with other variables such as extraction solvent $(38,39)$, air velocity $(21,40-42)$ or moisture content. (42) Summary of the selected publications involving ascorbic acid, total phenolic and flavonoid contents is presented in Table 1. 


\section{Meta-analysis}

All the studies that met the inclusion criteria were reported with small sample sizes; that is, the means were usually calculated from duplicate to triplicate measurements. While it is sufficient for comparing the means within the experiment, possible large sample variability with small sample size can cause bias when using response ratio. Therefore, a standardized mean was calculated for all the control and treatment groups using Eq. (1) and only one experiment from LTD group was excluded (standardized mean 1.97). The effect of drying temperature on the content of ascorbic acid, total phenolics and total flavonoids is presented in Table 2 . The results of each treatment group showed significant heterogeneity when compared with theoretical value from $\chi^{2}$ distribution at $\mathrm{k}-1$ degree of freedom. $R^{*}$ values $<1$ indicate decrease, and $R^{*}$ values $>1$ indicate increase in ascorbic acid, total phenolic and total flavonoids contents in comparison with the drying at $40^{\circ} \mathrm{C}$ (control). The lower the $R^{*}$ value, the greater the reduction of the compounds. The $\mathrm{R}^{*}$ value should also be interpreted as the increase or decrease of the compound's content in percentage (i.e., $\mathrm{R}^{*}=1.5$ means increase of $50 \%$ and $\mathrm{R}^{*}=0.8$ means decrease of $20 \%$ ).

\section{The effect of drying temperature on ascorbic acid content}

Ascorbic acid is an essential nutrient in the human diet, and its determination in fruits and vegetables serve as an indicator of the quality and efficacy of the drying process. Despite the abundance of studies related to ascorbic acid degradation, a limited number of reports were included in the meta-analysis (14, 17 and 9 studies for LTD, HTD and VHTD groups, respectively). According to the selected studies, drying plant-based food products at $50^{\circ} \mathrm{C}$ resulted in small but significant decrease $(5.3 \%)$ of ascorbic acid content $\left(R^{*}=0.947, \mathrm{P}=0.007\right)$ when compared with the control. Drying at $60^{\circ} \mathrm{C}$ (HTD group) and $70^{\circ} \mathrm{C}-80^{\circ} \mathrm{C}$ (VHTD group) enhanced the degradation of ascorbic acid with $R^{*}$ value to be $0.782(\mathrm{P}<0.001)$ and 0.470 
( $\mathrm{P}<0.001$ ), respectively (Table 2). These values corresponded to ascorbic acid decrease of $21.8 \%$ and $53.0 \%$, respectively.

Ascorbic acid can be easily degraded depending on various factors like temperature, drying time, moisture content, air velocity, sample geometry, the presence of enzyme, oxygen and metallic catalysts. (5) Considering the drying temperatures in the range from $40^{\circ} \mathrm{C}$ to $80^{\circ} \mathrm{C}$, the higher the drying temperature, the greater ascorbic acid losses have been observed for many plant-based products $(8,15,19,36,43)$; however, AA content may also increase when dried at $50^{\circ} \mathrm{C}$ as was observed in salak fruit (9), tomato slices (40) and pears. (37) Gamboa-Santos et al. (7) found similar amount of ascorbic acid in strawberries after drying at $40^{\circ} \mathrm{C}$ and $50^{\circ} \mathrm{C}$ for $7 \mathrm{~h}$. The initial moisture content of the products plays a key role during the thermal degradation of ascorbic acid. According to Santos and Silva (5), the effect of moisture content is predominant at the beginning of the drying process (high moisture content), while the temperature effect prevails when process continues (low moisture content). The loss of ascorbic acid during drying could be also attributed to a combination of thermal degradation and enzymatic oxidation. For instance, drying salak fruits at $40^{\circ} \mathrm{C}$ for a long time prevented the thermal degradation but initiated enzymatic oxidation. Drying at $50^{\circ} \mathrm{C}$ significantly shortened the drying period and prevented enzymatic oxidation while thermal degradation was insignificant and resulted in higher retention of ascorbic acid at $50^{\circ} \mathrm{C}$ than at $40^{\circ} \mathrm{C}$. Thermal degradation predominated when drying temperature was further increased to $60-70^{\circ} \mathrm{C}$. (9) Moreover, ascorbic acid may act as an oxidant for the reduction of $o$-chinones limiting the enzymatic browning in fruits dried at higher temperatures.

In a recent study of Kurozawa et al. (36), glass transition phenomenon has been attributed to the thermal degradation of ascorbic acid in papaya samples. The glass transition temperature is 
defined as the temperature at which an amorphous system changes from the glassy to the rubbery state. In the latter, the molecular mobility is accelerated, which results in higher reaction rates. Since glass transition temperature is a function of moisture content, papaya samples were in the rubbery state at the beginning of drying process and exhibited high degradation rate of ascorbic acid. At low moisture content, glass transition temperature increased allowing the papaya sample to pass from rubbery to glassy state where the mobility of reactants was reduced. Air velocity may have an influence on the drying kinetics and hence, affects the degradation of ascorbic acid. Higher flow rate increases drying rate due to the faster movement of water molecules from the surface of the solids to the drying medium resulting in lower retention of ascorbic acid as was determined for tomato slices (1.0 and $\left.2.0 \mathrm{~ms}^{-1}\right)(40)$ or papaya (1.0 and 1.32 $\mathrm{ms}^{-1}$ ). (36) Air velocity ranged from $0.3 \mathrm{~ms}^{-1}$ to $3.8 \mathrm{~ms}^{-1}$ across the studies included in the metaanalysis.

Based on the results of meta-analysis, drying plant-based products at $50^{\circ} \mathrm{C}$ leads only to a small difference in AA content in comparison with those dried at $40^{\circ} \mathrm{C}$. Generally, it may imply that ascorbic acid is not as heat-labile at these temperatures than at higher temperatures. Even though there are numerous variables affecting the AA content during drying, response ratio, as a metric in meta-analysis, allowed determining the effect of drying temperature on the retention or degradation of ascorbic acid within studies.

\section{The effect of drying temperature on total phenolic content}

Epidemiological studies give evidence that consumption of the variety of phenolic compounds present in plant-based food products decreases the risk of chronic diseases. $(62,63)$ Therefore, an increased interest in determination of the effect of drying conditions on the content of phenolic compounds was found during the search. For instance, using the term "phenolic" in 
combination with "dried or drying" and "fruit and vegetable" resulted in 863 records in Scopus database with a sharp increase in records from 2002 (5 records) to 2015 (123 records). A simple method (Folin-Ciocalteu's method) used for measuring the total phenolic content in natural matrices and the expanding use of chromatographic methods for quantification of phenolic individuals may also contribute to the increased number of publications.

For the meta-analysis, 22, 34 and 24 studies were used for LTD, HTD and VHTD treatment groups in our study, respectively. According to the weight response ratio, drying at $50^{\circ} \mathrm{C}$ and $60^{\circ} \mathrm{C}$ did not cause significant changes in TPC when compared with those drying at $40^{\circ} \mathrm{C}$ (Table 2). Estimated $R^{*}$ values were $1.002(\mathrm{P}=0.995)$ and $0.985(\mathrm{P}=0.699)$ for LTD and HTD groups, respectively. As can be seen from Table 2, the true $\mathrm{R}^{*}$ value for LTD and HTD groups lie within $95 \%$ confidence interval of $0.949-1.057$ and $0.915-1.060$, respectively. These findings indicate that drying at $50^{\circ} \mathrm{C}$ and $60^{\circ} \mathrm{C}$ does not result in significant changes in the content of TPC.

Decrease in TPC with the increase in drying temperature above $60^{\circ} \mathrm{C}$ can be explained by the thermal degradation $(11,13)$, ability of binding phenolic compounds to proteins and changes in chemical structure leading to the low extraction efficiency. (2) In general, the temperature has negative effect on the total phenolic content but the formation of phenolics at higher temperatures has also been observed. (1) Higher temperatures of drying are usually accompanied by a shorter drying time in order to achieve constant moisture content, which may decrease the extent of the degradation reactions as was found during drying of passion fruit (55), apple (17), Allium roseum leaves (21) and maqui berries. (24) At moderate drying temperature, long exposure to warm air may lead to the excessive oxidation of some phenolic compounds by the presence of oxygen (41) or by enzymatic activity $(23,44,64)$. Rodrigues et al. (64) determined high activity of polyphenoloxidase in apple samples after convective drying at $45^{\circ} \mathrm{C}$, which 
decreased with an increase of drying temperature in their study.

As was presented above, $\mathrm{R}^{*}$ values for LTD and HTD groups were close to one suggesting that the same retention of phenolics can be achieved regardless whether the plant-based food products are dried at $40^{\circ} \mathrm{C}, 50^{\circ} \mathrm{C}$, or $60^{\circ} \mathrm{C}$. Concerning VHTD group, a total phenolic content decrease of $21.2 \%$ was determined using response ratio $\left(R^{*}=0.788, \mathrm{P}=0.003\right)$. This finding indicates that more thermal decomposition of phenolic substances occurred during drying at higher temperatures (i.e., $70^{\circ} \mathrm{C}$ or $80^{\circ} \mathrm{C}$ ) in comparison with those dried at $40^{\circ} \mathrm{C}$.

\section{The effect of drying temperature on total flavonoid content}

Flavonoids constitute a large group of phenolic compounds naturally occurring in plant materials. Currently, there is an increasing interest in flavonoids research due to the beneficial effect on urinary tract infections, cognitive functions, age-related cognitive decline, cancer and cardiovascular disease. (65) However, flavonoids content in raw plant-based material may be affected by different processing method including drying.

Although the term "flavonoid" combined with terms "drying or dried" and "fruit or vegetable" resulted in hundreds of records, a limited number of studies meeting the inclusion criteria were found (Table 2). According to the results of the meta-analysis, no statistical differences in TFC were observed for all the treatment groups. Thus, the air-drying of plant-based food products at temperatures higher than $50^{\circ} \mathrm{C}$ did not significantly affect total flavonoids content in comparison with the low-temperature drying treatment, probably due to the high heterogeneity within a small number of studies. With respect to the $95 \%$ confidence interval, both reduction $\left(R^{*}<1\right)$ and increase $\left(R^{*}>1\right)$ of flavonoid constituents have been observed in all the treatment groups, although the $\mathrm{R}^{*}$ value 0.881 for HTD and 0.914 for VHTD groups may imply a slight decrease in TPC. An decrease of flavonoids content with the increase in drying temperature can be attributed 
to the binding of polyphenols to other compounds or to alterations in the chemical structure of phenolic compound hindering extraction or determination by the available methods. (15) On the other hand, an increase in TFC values with increasing drying temperature was reported for olivewaste cake (22) and loquat flower tea (26), which can be explained in the same way as discussed above; i.e., the higher the temperature the shorter drying time is necessary to achieve constant moisture content in the final product. Negative effect of drying temperature on the total flavonoids content was elucidated in the recent work of Rodríguez et al. (24), where the transition of various flavonoid constituents from the bound to the free form was observed during drying of maqui berries. For example, rutin hydrate in bound form decreased while rutin hydrate in free from increased with an increase in drying temperature. They also found that each constituent responded in different ways to the elevated temperature.

The total flavonoids content was determined using aluminium chloride assay in all the studies involved in the calculation of response ratio. In this assay, flavonoids react with hydroxyl in catecholic moiety in $\mathrm{B}$ ring; however, glycosylation prevents the chelation with $\mathrm{AlCl}_{3}(66)$. These results have to be interpreted with caution since a relatively small number of studies were used for the calculation of response ratio, particularly those incorporated into LTD group (5 studies). Beside, two studies were performed by the same collective of authors $(23,24)$, and probably in the same laboratory, which may interfere with the basic principle of meta-analysis (i.e. comparison of outcomes from independent studies).

The limitation of this study was incomplete data from all the research papers found in databases. A number of experiments involved in meta-analysis have to be reduced because some research articles did not provide standard deviation values that are necessary for the calculation of response ratio. There were also not enough data to analyze the effect of drying temperature at 
compound level; therefore, we included research articles in which total phenolics and flavonoids were determined.

\section{Conclusion}

The idea of quantifying the effect of drying temperatures on the content of nutrients has emerged as the response to the increasing popularity of raw foods. The raw food adherents eat fresh or minimally processed plant-based products, where the term "minimally" reflects drying at low temperature. Therefore, we extracted data from various studies dealing with air-drying of plantbased material and applied a meta-analytical approach in order to assess whether drying at $40^{\circ} \mathrm{C}$ is better than at higher temperatures. Ascorbic acid, total phenolic and total flavonoids contents were used as indicators due to their abundance in literature. Meta-analysis using response ratios showed that drying temperature significantly decreased ascorbic acid content without respect to other variables such as type of product, drying time, air velocity, geometry of samples, and sample load. Phenolics and flavonoids were not strongly influenced by the drying temperatures with the exception being the total phenolic content in plant-based food products dried at $70^{\circ} \mathrm{C}-$ $80^{\circ} \mathrm{C}$, where a significant decrease was observed in comparison with those dried at $40^{\circ} \mathrm{C}$. Metaanalysis proved to be an efficient way to summarize the effect of drying temperatures on the ascorbic acid, total phenolic and flavonoid contents in plant-based food material. Response ratio, as the effect size estimator, is able to indicate those temperatures that cause reduction or increase, and those that may cause both reduction and increase. Nevertheless, some calculations were performed using a limited number of experiments presenting a challenge for further research in this topic. 


\section{References}

1. Oliveira, S. M.; Brandão, T. R. S.; Silva, C. L. M. Influence of drying processes and pretreatments on nutritional and bioactive characteristics of dried vegetables: a review. Food Eng. Rev. 2016, 8, 134-163.

2. Kamiloglu, S.; Toydemir, G.; Boyacioglu, D.; Beekwilder, J.; Hall, R. D.; Capanoglu, E. A review on the effect of drying on antioxidant potential of fruits and vegetables. Crit. Rev. Food Sci. Nutr. 2016, 56, S110-S129.

3. Sablani, S. S. Drying of fruits and vegetables: retention of nutritional/functional quality. Drying Technol. 2006, 24, 123-135.

4. Russo, R. The raw food lifestyle: the philosophy and nutrition behind raw and live foods; North Atlantic Books: Berkeley, CA, 2009; 250 pp.

5. Santos, P.H.S.; Silva, M.A. Retention of vitamin C in drying processes of fruits and vegetables-a review. Drying Technol. 2008, 26, 1421-1437.

6. Chang, S. L.; Alasalvar, C.; Shahidi, F. Review of dried fruits: phytochemicals, antioxidant afficacies, and health benefits. J. Funct. Foods. 2016, 21, 113-132.

7. Gamboa-Santos, J.; Megías-Pérez, R.; Soria, A. C.; Olano, A.; Montilla, A.; Willamiel, M. Impact of processing conditions on the kinetic of vitamin $\mathrm{C}$ degradation and 2-furoylmethyl amino acid formation in dried strawberries. Food Chem. 2014, 153, 164-170.

8. García-Martínez, E.; Igual, M.; Martín-Esparza, M. E.; Martínez-Navarrete, N. Assessment of the bioactive compounds, color, and mechanical properties of apricots as affected by drying treatment. Food Bioprocess Technol. 2013, 6, 3247-3255.

9. Ong, S. P.; Law, C. L. Drying kinetics and antioxidant phytochemicals retention of salak fruit under different drying and pretreatment conditions. Drying Technol. 2011, 29, 429-441. 
10. Alean, J.; Chejne, F.; Rojano, B. Degradation of polyphenols during the cocoa drying process. J. Food Eng. 2016, 189, 99-105.

11. Bualuang, O.; Thamphueak, K. Effect of hot air convective drying temperature on physical and chemical properties of germinated sweet corn. Adv. Mat. Res. 2014, 1033-1034, 663-668. 12. Chang, C.-H.; Liu, Y.-C. Study on lycopene and antioxidant contents variations in tomatoes under air-drying process. J. Food Sci. 2007, 72(9), E532-E540.

13. Eim, V. S.; Urrea, D.; Rosselló, C.; García-Pérez, J. V.; Femenia, A.; Simal, S. Optimization of the drying process of carrot (Daucus carota $\mathrm{v}$. Nantes) on the basis of quality criteria. Drying Technol. 2013, 31, 951-962.

14. Kha, T. C.; Nguyen, M. H.; Roach, P. D. Effects of pre-treatments and air drying temperatures on colour and antioxidant properties of gac fruit powder. Int. J. Food Eng. 2011, 7(3), article 7.

15. Lemus-Mondaca, R.; Ah-Hen, K.; Vega-Gálvez, A.; Honores, C.; Moraga, N. O. Stevia rebaudiana leaves: effect of drying process temperature on bioactive components, antioxidant capacity and natural sweeteners. Plant Foods Hum. Nutr. 2016, 71, 49-56.

16. López-Vidaña, E. C.; Rojano, B. A.; Figueroa, I. P.; Zapata K.; Cortés, F. B. Evaluation of the sorption equilibrium and effect of drying temperature on the antioxidant capacity of the Jaboticaba (Myrciaria cauliflora). Chem. Eng. Commun. 2015, 203, 809-821.

17. Chen, W.; Guo, Y.; Zhang, J.; Zhang, X.; Meng, Y. Effect of different drying processes on the physicochemical and antioxidant properties of thinned young apple. Int. J. Food Eng. 2015, $11(2), 207-219$.

18. Chumroenphat, T.; Khanprom, I.; Butkhup, L. Stability of phytochemicals and antioxidant properties in ginger (Zingiber officinale Roscoe) rhizome with different drying methods. J. Herbs 
Spices Med. Plants 2011, 17, 361-374.

19. Guiné, R. P. F.; Henriques, F.; Barroca, M. J. Influence of drying treatments on the physical and chemical properties of cucumber. Food Measure. 2014, 8, 195-206.

20. Miranda, M.; Vega-Gálvez, A.; López, J.; Parada, G.; Sanders, M.; Aranda, M.; Uribe, E.; Di Scala, K. Impact of air-drying temperature nutritional properties, total phenolic content and antioxidant capacity of quinoa seed (Chenopodium quinoa Willd.). Ind. Crops Prod. 2010, 32, $258-263$.

21. Said, L. B. H.; Najjaa, H.; Neffati, M.; Bellagha, S. Color, phenolic and antioxidant characteristic changes of Allium roseum leaves during drying. J. Food Qual. 2013, 36, 403-410.

22. Uribe, E.; Lemus-Mondaca, R.; Pasten, A.; Astudillo, S.; Vega-Gálvez, A.; Puente-Díaz, L.;

Di Scala, K. Dehydrated olive-waste cake as a source of high value-added bioproduct: Drying kinetics, physicochemical properties, and bioactive compounds. Chil. J. Agric. Res. 2014a, 74(3), 293-301.

23. Rodríguez, K.; Ah-Hen, K.; Vega-Gálvez, A.; López, J.; Quispe-Fuentes, I.; LemusMondaca, R.; Gálvez-Ranilla, L. Changes in bioactive compounds and antioxidant activity during convective drying of murta (Ugni molinae T.) berries. Int. J. Food Sci. Technol. 2014, 49, $990-1000$.

24. Rodríguez, K.; Ah-Hen, K.; Vega-Gálvez, A.; Vásquez, V.; Quispe-Fuentes, I.; Rojas, P.; Lemus-Mondaca, R. Changes in bioactive components and antioxidant capacity of maqui, Aristotelia chilensis [Mol] Stuntz, berries during drying. LWT-Food Sci. Technol. 2016, 65, $537-542$

25. Uribe, E.; Lemus-Mondaca, R.; Vega-Gálvez, A.; Zamorano, M.; Quispe-Fuentes, I.; Pasten, A.; Di Scala, K. Influence of process temperature on drying kinetics, physicochemical properties 
and antioxidant capacity of the olive-waste cake. Food Chem. 2014b, 147, 170-176.

26. Zheng, M.; Xia, Q.; Lu, S. Study on drying methods and their influences on effective components of loquat flower tea. LWT-Food Sci. Technol. 2015, 63, 14-20.

27. Boreinstein, M.; Hedges, L. V.; Higgins, J. P. T.; Rothstein, H. R. Introduction to metaanalysis; John Wiley \& Sons: Chichester, 2009; 452 pp.

28. Palupi , E.; Jayanegara, A.; Ploeger, A.; Kahl, J. Comparison of nutritional quality between conventional and organic dairy products: a meta-analysis. J. Sci. Food Agric. 2012, 92, 2774 2781.

29. Średnicka-Tober, D.; Barański, M.; Seal, C.; Sanderson, R.; Benbrook, C.; Steinshamn, H.; Gromadzka-Ostrowska, J.; Rembiakowska, E.; Skwarło-Sońta, K.; Eyre, M.; Cozzi, G.; Larsen, M. K.; Jordon, T.; Niggli, U.; Sakowski, T.; Calder, P. C.; Burdge, G. C.; Sotiraki, S.;

Stefanakis, A.; Yolcu, H.; Stergiadis, S.; Chatzidimitriou, E.; Butler, G.; Stewart, G.; Leifert, C. Composition differences between organic and conventional meat: a systematic literature review and meta-analysis. Br. J. Nutr. 2016, 115, 994-1011.

30. MacDonald, L. E.; Brett, J.; Kelton, D.; Majowicz, S. E.; Snedekker, K.; Sargeant, J. M. A systematic review and meta-analysis of the effects of pasteurization on milk vitamins, and evidence for raw milk consumption and other health-related outcomes. J. Food Prot. 2011, 74, $1814-1832$.

31. Murador, D. C.; da Cunha, D. T.; de Rosso, V. V. Effects of cooking techniques on vegetace pigments: a meta analytic approcach to carotenoid and anthocyanin levels. Food Res. Int. 2014, $65,177-183$.

32. Keikotlhaile, B. M.; Spanoghe, P.; Steurbaut, W. Effects of food processing on pesticide residues in fruits nad vegetables: a meta-analysis approach. Food Chem. Toxicol. 2010, 48, 1-6. 
33. Hedges, L. V.; Gurevitch, J.; Curtis, P. S. The meta-analysis of response ratios in experimental ecology. Ecology 1999, 80, 1150-1156.

34. Lajeunesse, M. Bias and correction for the log response ratio in ecological meta-analysis. Ecology 2015, 96, 2056-2063.

35. Altman, D. G.; Bland, J. M. How to obtain the P value from a confidence interval. BMJ 2011, 343:d2304.

36. Kurozawa, L. E.; Terng, I.; Hubinger, M. D.; Park, K. J. Ascorbic acid degradation of papaya during drying: Effect of process conditions and glass transition phenomena. J. Food Eng. 2014, $123,157-164$.

37. Mrad, N. D.; Boudhrioua, N.; Kechau, N.; Courtois, F.; Bonazzi, C. Influence of drying temperature on kinetics, physicochemical properties, total phenolic content and ascorbic acid in pears. Food Bioprod. Process. 2012, 90, 433-441.

38. Al-Rawahi, A. S.; Rahman, M. S.; Guizani, N.; Essa, M. M. Chemical composition, water sorption isotherm, and phenolic contents in fresh and dried pomegranate peels. Drying Technol. 2013, 31, 257-263.

39. Yi, W.; Wetzstein, H. Y. Effects of drying and extraction conditions on the biochemical activity of selected herbs. Hort. Science 2011, 46(1), 70-73.

40. Abano, E. E.; Ma, H; Qu, W. Optimization of drying conditions for quality dried tomato slices using response surface methodology. J. Food Process. Preserv. 2014, 38(3), 996-1009. 41. Daniel, D. L.; Huerta, B. E. B.; Sosa, I. A.; Mendoza, M. G. V. Effect of fixed bed drying on the retention of phenolic compounds, antocyanins and antioxidant activity of roselle (Hibiscus sabdariffa L.). Ind. Crops Prod. 2012, 40, 268-276.

42. Vega-Gálvez, A.; Ah-Hen, K.; Chacana, M.; Vergara, J.; Martínez-Monzó, J.; García- 
Segovia, P.; Lemus-Mondaca, R.; Di Scala, K. Effect of temperature and air velocity on drying kinetics, antioxidant capacity, total phenolic content, colour, texture and microstructure of apple (var. Granny Smith) slices. Food Chem. 2012, 132, 51-59.

43. Marey, S.; Shoughy, M. Effect of temperature on the drying behaviour and quality of citrus peels. Int. J. Food Eng. 2016, 12(7), 661-671.

44. Bahloul, N.; Boudhrioua, N.; Kouhila, M.; Kechaou, N. Effect of convective solar drying on colour, total phenols and radical scavenging activity of olive leaves (Olea europea L.). Int. J. Food Sci. Technol. 2009, 44, 2561-2567.

45. Bchir, B.; Besbes, S.; Karoui, R.; Attia, H.; Paquot, M.; Blecker, C. Effect of air-drying conditions on physico-chemical properties of osmotically pre-treated pomegranate seeds. Food Bioprocess. Technol. 2012, 5, 1840-1852.

46. Chong, K. L.; Lim, Y. Y. Effects of drying on the antioxidant properties of herbal te from selected Vitex species. J. Food Qual. 2012, 35, 51-59.

47. Santos, S. C. R. V. L.; Guiné, R. P. F.; Barros, A. Effect of drying temperatures on the phenolic composition and antioxidant activity of pears of Rocha variety (Pyrus communis L.). Food Measure. 2014, 8, 105-112.

48. Igual, M.; García-Martínez, E.; Martín-Esparza, M. E.; Martínez-Navarrete, N. Effect of processing on the drying kinetics and functional value of dried apricot. Food Res. Int. 2012, 47, $284-290$

49. Khawas, P.; Dash, K. K.; Das, A. J.; Deka, S. C. Drying characteristics and assessment of physicochemical and microstructural properties of dried culinary banana slices. Int. J. Food Eng. 2015, 11(5), 667-678.

50. Lemus-Mondaca, R.; Miranda, M.; Grau, A. A.; Briones, V.; Villalobos, R.; Vega-Gálvez, A. 
Effect of osmotic pretreatment on hot air drying kinetics and quality of Chilean papaya (Carica pubescens). Drying Technol. 2009, 27, 1105-1115.

51. Ling, A. L. M.; Yasir, S.; Matanjun, P.; Abu Bakar, M. F. Effect of different drying techniques on the phytochemical content and antioxidant activity of Kappaphycus alvarezii. J. Appl. Phycol. 2015, 27, 1717-1723.

52. Liu, Y.; Wu, J.; Miao, S.; Chong, C.; Sun, Y. Effect of a modified atmosphere on drying and quality characteristics of carrots. Food Bioprocess. Technol. 2014, 7, 2549-2559. 53. Mota, C. L.; Luciano, C.; Dias, A.; Barroca, M. J.; Guiné, R. P. F. Convective drying of onion: Kinetics and nutritional evaluation. Food Bioprod. Process. 2010, 88, 115-123.

54. Muratore, G.; Rizzo, V.; Licciardello, F.; Maccarone, E. Partial dehydration of cherry tomato at different temperature, and nutritional quality of the products. Food Chem. 2008, 111, 887891.

55. Nascimento, E. M. G. C.; Mulet, A.; Ascheri, J. L. R.; de Carvalho, C. W. P.; Cárcel, J. A. Effect of high-intensity ultrasound on drying kinetics and antioxidant properties of passion fruit peels. J. Food Eng. 2016, 170, 108-118.

56. Puente-Díaz, L.; Ah-Hen, K.; Vega-Gálvez, A.; Lemus-Mondaca, R.; Di Scala, K. Combined infrared-convective drying of murta (Ugni molinae Turcz) berries: kinetic modelling and quality assessment. Drying Technol. 2013, 31, 329-338.

57. Rizzo, V.; Clifford, M. N.; Brown, J. E.; Siracusa, L.; Muratore, G. Effects of processing on the polyphenol and phenolic acid content and antioxidant capacity of semi-dried cherry tomatoes (Lycopersicon esculentum M.). J. Food Sci. Agric. 2016, 96, 2040-2046.

58. Sagrin, M. S.; Chong, G. H. Effect of drying temperature on the chemical and physical properties of Musa acuminate Colla (AAA group) leaves. Ind. Crops Prod. 2013, 45, 430-434. 
59. Tello-Ireland, C.; Lemus-Mondaca, R.; Vega-Gálvez, A.; López, J.; Di Scala, K. Influence of hot-air temperature on drying kinetics, functional properties, colour, phycobiliproteins, antioxidant capacity, texture and agar yield of alga Glacilaria chilensis. LWT-Food Sci. Technol. 2011, 44, 2112-2118.

60. Urun, G. B.; Yaman, Ü. R.; Köse, E. Determination of drying characteristics and quality properties of eggplant in different drying conditions. Ital. J. Food Sci. 2015, 27, 459-467.

61. Vásquez-Osorio, D.; Acosta, L. M. V.; Hincapié, G. A. Analysis of nutritional and functional properties of dry guava. Ing. Univ. Bogotá (Colombia) 2014, 18(1), 159-175.

62. Shahidi, F.; Ambigaipalan, P. Phenolics and polyphenolics in foods, beverages and spices: antioxidant activity and health effects - A review. J. Funct. Food 2015, 18, 820-897.

63. Gutiérrez-Grijalva, E. P.; Ambriz-Pére, D. L.; Leyva-López, N.; Castillo-López, R. I.; Heredia, J. B. Review: dietary phenolic compounds, health benefits and bioaccessibility. Arch. Latinoam. Nutr. 2016, 66, 87-100.

64. Rodrigues, S; Fernandes, F. A. N.; García-Pérez, J. V.; Cárcel, J. A. Influence of ultrasoundassisted air-drying and conventional air-drying on the activity of apple enzymes. J. Food Process. Preserv. 2016, in press.

65. Rodriguez-Mateos, A.; Vauzour, D; Krueger, C. G.; Shanmuganayagam, D.; Reed, J.; Calani, L; Mena, P.; del Rio, D; Crozier, A. Bioavailability, bioactivity and impact on health of dietary flavonoids and related compounds: an update. Arch. Toxicol. 2014, 88, 1803-1853. 66. Granato, D.; Santos, J. S.; Maciel, L. G.; Nunes, D. S. Chemical perspective and criticism on selected analytical methods used to estimate the total content of phenolic compounds in food matrices. Trends Anal. Chem. 2016, 80, 266-279. 
Table 1 Plant-based food products included in meta-analysis

\begin{tabular}{|c|c|c|}
\hline Commodity & $\begin{array}{l}\text { Temperatures included in meta- } \\
\text { analysis }\end{array}$ & Bioactive compounds \\
\hline Strawberry (7) & $40^{\circ} \mathrm{C}, 50{ }^{\circ} \mathrm{C}, 60{ }^{\circ} \mathrm{C}, 70^{\circ} \mathrm{C}$ & Ascorbic acid \\
\hline Apricots (8) & $40^{\circ} \mathrm{C}, 60^{\circ} \mathrm{C}$ & Ascorbic acid \\
\hline Salak fruit (9) & $40^{\circ} \mathrm{C}, 50^{\circ} \mathrm{C}, 70^{\circ} \mathrm{C}$ & Ascorbic acid, TPC \\
\hline Cocoa bean (10) & $40^{\circ} \mathrm{C}, 50^{\circ} \mathrm{C}, 60^{\circ} \mathrm{C}$ & TPC \\
\hline Sweet corn (11) & $40^{\circ} \mathrm{C}, 60^{\circ} \mathrm{C}, 70^{\circ} \mathrm{C}$ & TPC \\
\hline Tomatoes, six cultivars (12) & $40^{\circ} \mathrm{C}, 80^{\circ} \mathrm{C}$ & TPC, TFC \\
\hline Carrots (13) & $40^{\circ} \mathrm{C}, 50{ }^{\circ} \mathrm{C}, 60^{\circ} \mathrm{C}, 70^{\circ} \mathrm{C}$ & ТPC \\
\hline Gac fruit (14) & $40{ }^{\circ} \mathrm{C}, 50{ }^{\circ} \mathrm{C}, 60{ }^{\circ} \mathrm{C}, 70^{\circ} \mathrm{C}$ & TPC \\
\hline Leaves (Stavia rebaudiana) (15) & $40{ }^{\circ} \mathrm{C}, 50{ }^{\circ} \mathrm{C}, 60^{\circ} \mathrm{C}, 70^{\circ} \mathrm{C}$ & Ascorbic acid, TPC, TFC \\
\hline Jaboticaba fruit (16) & $40^{\circ} \mathrm{C}, 50^{\circ} \mathrm{C}, 60^{\circ} \mathrm{C}$ & \\
\hline $\begin{array}{l}\text { Apple (TYA cultivar “Red Fuji”) } \\
\text { (17) }\end{array}$ & $40^{\circ} \mathrm{C}, 60^{\circ} \mathrm{C}, 80^{\circ} \mathrm{C}$ & ТPC \\
\hline Ginger rizome (18) & $40^{\circ} \mathrm{C}, 50^{\circ} \mathrm{C}, 60^{\circ} \mathrm{C}, 70^{\circ} \mathrm{C}$ & ТPC \\
\hline Cucumber (19) & $40^{\circ} \mathrm{C}, 60^{\circ} \mathrm{C}$ & Ascorbic acid, TPC \\
\hline Quinoa seed (20) & $40^{\circ} \mathrm{C}, 50^{\circ} \mathrm{C}, 60^{\circ} \mathrm{C}, 70^{\circ} \mathrm{C}$ & ТPC \\
\hline Leaves (Allium roseum) (21) & $40^{\circ} \mathrm{C}, 50^{\circ} \mathrm{C}, 60^{\circ} \mathrm{C}$ & TPC, TFC \\
\hline Olive cake (Picual variete) (22) & $40^{\circ} \mathrm{C}, 50^{\circ} \mathrm{C}, 60^{\circ} \mathrm{C}, 70^{\circ} \mathrm{C}$ & $\mathrm{TPC}$ \\
\hline Murta berry (23) & $40{ }^{\circ} \mathrm{C}, 50{ }^{\circ} \mathrm{C}, 60^{\circ} \mathrm{C}, 70^{\circ} \mathrm{C}$ & $\mathrm{TPC}, \mathrm{TFC}$ \\
\hline Maqui berry (24) & ${ }^{\circ} \mathrm{C}, 50^{\circ} \mathrm{C}, 60^{\circ} \mathrm{C}, 70^{\circ} \mathrm{C}$ & TPC, TFC \\
\hline Olive cake (Frantoio variete) (25) & $40^{\circ} \mathrm{C}, 50{ }^{\circ} \mathrm{C}, 60{ }^{\circ} \mathrm{C}, 70^{\circ} \mathrm{C}$ & TPC, TFC \\
\hline Loquat flower (26) & $40{ }^{\circ} \mathrm{C}, 60^{\circ} \mathrm{C}, 80{ }^{\circ} \mathrm{C}$ & TPC \\
\hline Papaya (36) & $40{ }^{\circ} \mathrm{C}, 50{ }^{\circ} \mathrm{C}, 60{ }^{\circ} \mathrm{C}, 70^{\circ} \mathrm{C}$ & Ascorbic acid \\
\hline Pear (37) & $40^{\circ} \mathrm{C}, 50{ }^{\circ} \mathrm{C}, 60^{\circ} \mathrm{C}, 70^{\circ} \mathrm{C}$ & Ascorbic acid, TPC \\
\hline Pomegranate peel (38) & $40^{\circ} \mathrm{C}, 60^{\circ} \mathrm{C}$ & ТPC \\
\hline $\begin{array}{l}\text { Rosemary, motherwort, peppermint } \\
\text { (39) }\end{array}$ & $40^{\circ} \mathrm{C}, 70^{\circ} \mathrm{C}$ & ТPC \\
\hline $\begin{array}{l}\text { Tomatoe (Hong Xui hydrid no. } 1 \\
\text { variety) (40) }\end{array}$ & $40^{\circ} \mathrm{C}, 50^{\circ} \mathrm{C}, 60^{\circ} \mathrm{C}$ & Ascorbic acid \\
\hline Roselle (Hibiscus sabdariffa L.) (41) & $40^{\circ} \mathrm{C}, 60^{\circ} \mathrm{C}, 80^{\circ} \mathrm{C}$ & ТPC \\
\hline Apple (Granny Smith variete) (42) & $40{ }^{\circ} \mathrm{C}, 60^{\circ} \mathrm{C}, 80^{\circ} \mathrm{C}$ & ТPC \\
\hline
\end{tabular}




\begin{tabular}{|c|c|c|}
\hline Orange and mandarin peels (43) & $40^{\circ} \mathrm{C}, 50^{\circ} \mathrm{C}, 60^{\circ} \mathrm{C}, 70^{\circ} \mathrm{C}$ & Ascorbic acid \\
\hline Olive leave (44) & $40^{\circ} \mathrm{C}, 50^{\circ} \mathrm{C}, 60^{\circ} \mathrm{C}$ & $\mathrm{TPC}$ \\
\hline Pomegranate seed (45) & $40{ }^{\circ} \mathrm{C}, 50{ }^{\circ} \mathrm{C}, 60^{\circ} \mathrm{C}$ & TPC \\
\hline $\begin{array}{l}\text { Leaves (Vitex nefundo, V. trofolia) } \\
\text { (46) }\end{array}$ & $40{ }^{\circ} \mathrm{C}, 50{ }^{\circ} \mathrm{C}, 70^{\circ} \mathrm{C}$ & TPC \\
\hline Pear (47) & $40^{\circ} \mathrm{C}, 60^{\circ} \mathrm{C}$ & $\mathrm{TPC}$ \\
\hline Apricot (48) & $40{ }^{\circ} \mathrm{C}, 60^{\circ} \mathrm{C}$ & $\mathrm{TPC}$ \\
\hline Banana (Musa ABB) (49) & $40^{\circ} \mathrm{C}, 50{ }^{\circ} \mathrm{C}, 60^{\circ} \mathrm{C}, 70^{\circ} \mathrm{C}$ & TPC \\
\hline Рapaya (50) & $40^{\circ} \mathrm{C}, 60^{\circ} \mathrm{C}, 80^{\circ} \mathrm{C}$ & Ascorbic aci \\
\hline $\begin{array}{l}\text { Seaweeds (Kappaphycus alvarezii) } \\
\text { (51) }\end{array}$ & $40^{\circ} \mathrm{C}, 80^{\circ} \mathrm{C}$ & \\
\hline Carrot (52) & $40^{\circ} \mathrm{C}, 50^{\circ} \mathrm{C}, 60^{\circ} \mathrm{C}, 70^{\circ} \mathrm{C}$ & Ascorbic acid \\
\hline Onion (Mondego variete) (53) & $40{ }^{\circ} \mathrm{C}, 50{ }^{\circ} \mathrm{C}, 70{ }^{\circ} \mathrm{C}$ & Ascorbic acid \\
\hline $\begin{array}{l}\text { Cherry tomatoe (Shiren cultivar) } \\
\text { (54) }\end{array}$ & $40{ }^{\circ} \mathrm{C}, 60^{\circ} \mathrm{C}, 80^{\circ} \mathrm{C}$ & Ascorbic \\
\hline Passion fruit (55) & $40^{\circ} \mathrm{C}, 50^{\circ} \mathrm{C}, 60^{\circ} \mathrm{C}, 70^{\circ} \mathrm{C}$ & TPC \\
\hline Murta berry (56) & $40^{\circ} \mathrm{C}, 50^{\circ} \mathrm{C}, 60^{\circ} \mathrm{C}$ & $\mathrm{TPC}$ \\
\hline Cherry tomatoe (57) & $40^{\circ} \mathrm{C}, 60^{\circ} \mathrm{C}, 80^{\circ} \mathrm{C}$ & TPC \\
\hline Leaves (Musa acuminata) (58) & $40^{\circ} \mathrm{C}, 50^{\circ} \mathrm{C}, 60^{\circ} \mathrm{C}$ & ТPC \\
\hline Algae (Glacilaria) (59) & $40^{\circ} \mathrm{C}, 50^{\circ} \mathrm{C}, 60^{\circ} \mathrm{C}, 70^{\circ} \mathrm{C}$ & ТPC \\
\hline Eggplant (60) & $40{ }^{\circ} \mathrm{C}, 50^{\circ} \mathrm{C}, 60^{\circ} \mathrm{C}$ & Ascorbic acid \\
\hline Guava (61) & $40^{\circ} \mathrm{C}, 50^{\circ} \mathrm{C}, 60^{\circ} \mathrm{C}, 70^{\circ} \mathrm{C}$ & Ascorbic acid \\
\hline
\end{tabular}

TPC, total phenolic content; TFC, total flavonoid content 
Table 2 Meta-analysis of the effect of drying temperature on ascorbic acid, total phenolic and total flavonoid contents in plant-based food products

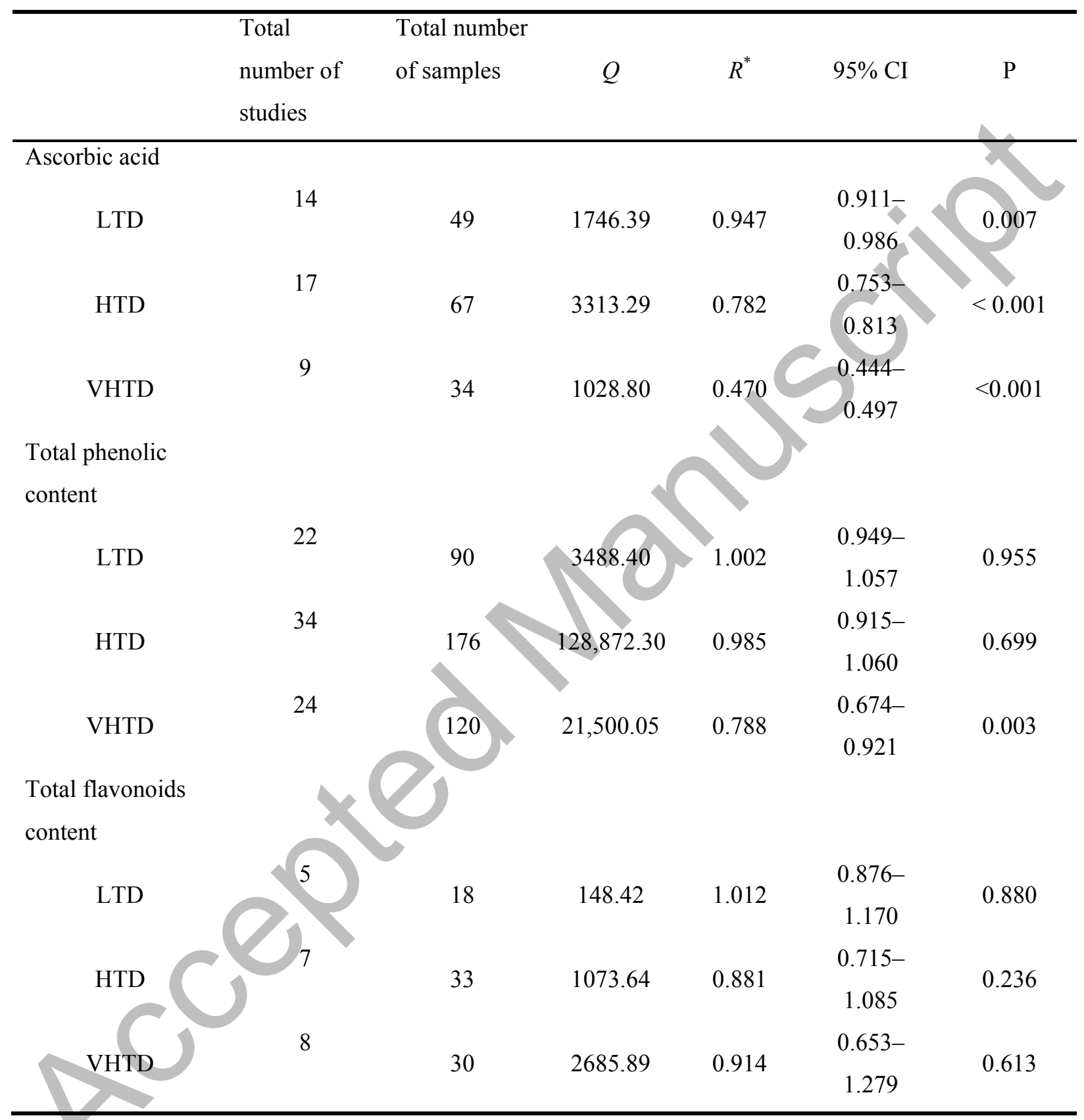

LTD, low temperature difference $\left(40^{\circ} \mathrm{C}\right.$ vs. $\left.50^{\circ} \mathrm{C}\right)$; HTD, high temperature difference $\left(40^{\circ} \mathrm{C}\right.$ vs. $\left.60^{\circ} \mathrm{C}\right)$; VHTD, very high temperature difference $\left(40^{\circ} \mathrm{C}\right.$ vs. $\left.70^{\circ} \mathrm{C}-80^{\circ} \mathrm{C}\right) ; Q, Q$-statistic value; $R^{*}$-weighted response ratio; $95 \% \mathrm{CI}$, 95\% confidence interval; $\mathrm{P}$, probability level. 